\title{
ラテックスによる水性接着剤
}

\section{Water Adhesive Using Natural Rubber Latex}

Takashi SUGAI (REGITEX Co., Ltd., 1411-2 Kamiechi, Atsugi, Kanagawa 243-0801, Japan)

The brief outline of water adhesive using natural rubber latex and modified natural rubber latex are introduced. Also the new trend uses of the functionality modified natural rubber latex are mentioned.

(Received on June 12, 2015)

Key Words : Grafted NR Latex, Depolymerized NR Latex, MG Latex, Mechanical Stability, Pressure Sensitive Glue

1. は じ めに

会社の設立時に日本ゴム協会副会長を務められた沖倉元 治氏（当時中央ラテックス技術研究会理事長）に大変押世 話になった．以前，直接ラテックスの基礎的な試験方法や ラテックスの変性法についてご教授頂く機会があり，会社 設立後も技術顧問を引受けて頂き多くの貴重なアドバイス を頂いた．固形ゴムに関する研究資料・報告書・特許情報 は数多いが，天然ゴムラテックスに関するものは少なく， 先生が編集委員長である「エマルジョン・ラテックスハン ドブック」は貴重なバイブルのような本であった1).その

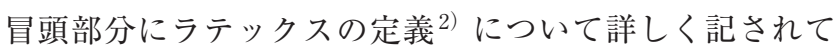
いるので参考にされたい. ラテックス（Latex）はポリマ 一が微粒子状で水に安定に分散したもので，元来ゴムの木 から採取された天然ゴム乳液を指しているが，現在はより 広義の意味でつかわれている.接着剤や粘着剤の分野では, 天然ゴムラテックス (natural rubber latex, 以下NRラテ ックス）とその化学変性品, モノマーを水中に乳化分散し 重合した合成ゴムラテックス (synthetic rubber latex) とこれらを原料とするものを広く指していることが多い. また，ディッピング（浸漬法）により薄いゴム皮膜成型品 を加工する分野では，その柔らかく伸びの大きい成型品を ラテックスと呼ぶこともある。本報告では天然ゴムを取り 扱っている方々には「釈迦に説法」の部分も多いと思うが, 主に天然ゴムラテックス抢よびその変性体を使用した粘・ 接着片などの概要及び動向を紹介し, 最後に天然ゴムラテ
ックスの最近の化学変性の研究についても述べる.

\section{2. 天然ゴムラテックスの生産地}

現在使用されている天然ゴム (NR) の98\%はアジアで 栽培されているが，タイヤをはじめとする旺盛な需要とそ の重要性, 価格の高騰も相まってアフリカや中南米などの 熱帯気候地域, 南・北緯 15 度圈内で植林と生産が急ピッ チで拡大している。近年では, 品種改良によって, 北緯 18 度以北に位置する中国の海南島や雲南省, あるいはブ ラジルなどでも栽培される，今後もモータリゼーションが さらに進み，年々需要が高まると予想されている。 また将 来の供給多様性から, 熱帯気候地域以外で生産可能な, Hevea 樹 ${ }^{3)}$ 以外の植物, 例えば, グアユーレ, ロシアタ ンポポ4) 等からの採取応用研究が進められている.

昭和生まれの私の年代では, NRの産地といえばまずマ レーシアが頭に浮かび，実際に取扱うNRラテックスも 2006年頃までは $100 \%$ マレーシア産を使用していた，その 後, マレーシアはゴムの樹からパーム梛子に植え替えが進 み, NRラテックスの生産量は将来的に減少傾向になるこ

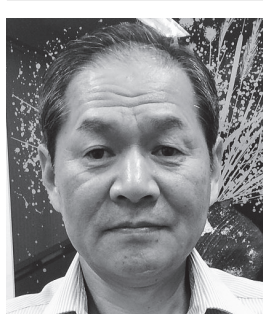

菅井 敬：株レヂテックス（テ254-0801 神奈 川県厚木市上依知 1411-2）代表取締役. 昭和 54 年 山形大学工学部化学工学科卒業. 平成 4 年 5 月 株レヂテックス創立，取締役開発部長 平成 17 年 代表取締役。専門は，天然ゴムラ テックス系の粘・接着剂, 天然ゴムラテック ス・樹脂エマルジョンの成型加工品, ジエン 系ゴムの表面処理受託加工, 各種洗浄剂. 日 本ゴム協会賛助会員 
表1天然ゴム生産量国別ランキング（2013年）

\begin{tabular}{|c|l|c|}
\hline 順位 & 国 名 & 生産量〔単位 : トン〕 \\
\hline 1 & タイ & $3,863,000$ \\
\hline 2 & インドネシア & $3,107,544$ \\
\hline 3 & ベトナム & 949,100 \\
\hline 4 & インド & 900,000 \\
\hline 5 & 中国 & 864,800 \\
\hline 6 & マレーシア & 826,421 \\
\hline
\end{tabular}

出展・参照 : FAO (Food and Agriculture Organization) ${ }^{5)}$

とから, その後タイやベトナムのラテックスを試験評価し， 現在では限定的ではあるもののマレーシア以外のラテック スで同等に化学変性が行えるまでになった．現実的に顧客 ユーザーから，供給について問合せが入るようになった． 世界の NR 国別生産量（表1：2013年）では，マレーシア はべトナム，インド，中国に生産量で抜かれ 3 位から 6 位 にランキングを落とし，2011年比では生産数量も減少し ている.

マレーシアの計画ではゴムの生産を再度増やす方針であ るが，すでに $95 \%$ はパーム楖子で，事業会社はアフリカな どに技術者を派遣し，ゴムの植林事業の進出を果たしてい る事もあり，純粋にマレーシア産の NRが増加するかどう か注目されているＮRラテックスはHevea樹から採取さ れるため，生産国によって品質がどの程度変わるかという 点でラテックスに関する研究資料も少なく，また当初それ ほど心配はしていなかった。しかし，各地のラテックスを 取寄せ，同一条件下でMMAのグラフト反応などの化学変 性した場合，無視できないさまざまな挙動が確認された. 実際，NRラテックスの変性体の同等製品をマレーシア品 以外で製造するまでに数年を費やした。それは，ほとんど の NRの用途がタイヤ等の加硫タイプであり，NRラテッ クスの場合でもそのほとんどが手袋用などの加硫製品のた め，グラフト共重合などの化学反応に影響を与える微量成 分（硫黄や酸化亜鉛など）の存在に生産者や精製メーカー が問題視もせず，コントロールもできていなかった。この 金属成分の多くは，NR ラテックスの保存剤に原因がある ことが知られていて，マレーシア以外に多い小規模農園の 生産者がその使用量を厳密に管理することは難しいとされ ていた。それでも，近年のマレーシアの動向や価格変動の 激しい状況下では供給の安定を確保することが急務で，安 定した品質と製品供給はクリヤーしなければならない最重 要課題であったＮR ラテックスの非ゴム分を極力除き均 一化する方法もあるが，NRラテックス本来の自着性や凝 集力などの性能を低下させては意味がない．非ゴム成分の 中には，耐酸化性が有り，高分子量を維持する役割を持つ ものや，表面粘着を抑え，のり面同士を強く圧着した場合 に流動性が発現し，自着する性質が失われる事がある。し たがって非ゴム分に大きな差が無く,産地の特長や傾向を， 年間を通じて把握し，かつNRラテックスの特長を活かし
た化学変性が出来るように製造管理を㧍こなった。現在も， 日本で使用するNRラテックスはマレーシア産が主流だ が，新製品の一部や夕イ工場では夕イ産のラテックスを使 用しており，粘着性などの性能の差は見られない。さらに 今後も世界の需要動向により産地の状況は刻々と変化する ことが予想されるため，時間をかけてこれらの国やその他 の国の NR ラテックスの評価をすすめ対応することが求め られている。

我々ラテックスを取り扱う者が恵まれているのは，タイヤ を中心とした需要の増加とともに天然ゴムラテックス生産量 の伸びが今後も持続する事が予想され，継続的な植林により 生産可能で枯渇する資源では無くある程度時間を掛けて開発 ができるということである。 その意味でNR ラテックスは有 用な資源で今後も積極的に用途展開を考え，その優れた特長 を活かした製品を提案していきたいと考えている.

NRのライフサイクルは, 図 1 に示す種子から 6 ～7年で 成長し，光合成により二酸化炭素を吸収し，天然ゴムの原 料である樹液（NRラテックス）を生成し採取する． 30 年 ほどで伐採されまた新たに植林される，NRが素材として 優れているだけでなく, 図2 2 に示すように植物資源として 持続可能な有用な資源であることはよく知られている. NR ラテックス及びその化学変性品はその優れた物性はも ちろんのこと，環境的にも推奨される原料であることを伝 えていきたいと考えている. サスティナブルデベロップメ ントの一つの重要な素材ととらえている.

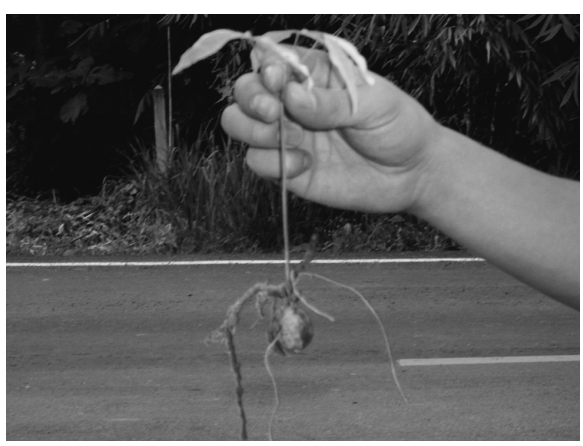

図 1 タイのゴム樹植林地のゴムの樹の種子（Thailand）

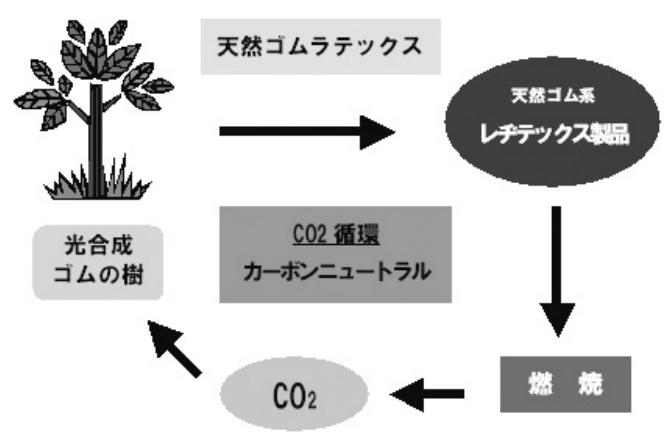

図2 天然ゴムのライフサイクル 


\section{3. 接着剤向け原料天然ゴムラテックスの主な種類}

\section{1 一般的な NRラテックス}

主なNRラテックスを表2にまとめる.

NR ラテックスはLA（Low ammonia）タイプとHA (High ammonia) タイプが一般的で，いずれも保存剤 （殺菌剤）を使用しているＨAタイプはアンモニアを使 用し，LAタイプは主にTZを使用している。厳密にはフ イールドラテックスの収集工程でチウラム系の TZを使用 している場合がほとんどで，HAタイプにも極めて微量で はあるが硫黄，亜鉛成分が検出されることが多い。これら の微量成分を嫌う用途には採取時から別工程で管理される 必要がある。これらのラテックスを化学変性用途に使用す る場合，化学反応に少なからず影響を与えるので，明確に 区別しなくてはならない．2回遠心分離ラテックス（DCLatex）でも非ゴム分が少なくこれらの微量成分も少ない 傾向にあるが，同時にタンパク質を含む非ゴム分が減少す ることにより物性の低下や加硫の遅延などの影響が出る場 合がある.NRラテックスの物性とタンパク質量との関連 性は数多く取り上げられているが，その他の微量成分との 関連性についてはまだ研究の余地が多く残されている。多 ンパク質やその他の微量成分に応じて接着剤としての機 能，例えば粘着性・凝集力・伸び，フィルムの引張強度， 加硫速度，耐水性，耐熱性などに影響を及ぼすことがある。

通常のNR ラテックスの被膜は，伸びが約 $1000 \%$ ，引張 強度が約 $10 \mathrm{MPa}$ 程度で，また広い温度域で柔軟性に富ん でいる.また自着性があり水性接着片に好適な水分の蒸発, 乾燥後に接着作業ができる特長を持つなど全般に優れた性 質をもっている．またその柔軟性を活かして靴や手袋など の敏感で複雑な動きや感覚に追従するもの,クッション性, 反撥性，シール性，衝撃吸収性を利用した，敷物や枕，纎 維の仮止めや縫い目部分の防水などには定評があり，現在 でも広く支持され，使用されている。しかし，よりニーズ

表 2 濃縮 NR ラテックス分類

\begin{tabular}{|c|c|c|}
\hline Latex の種類 & DRC $(\%)$ & 性質·特長 \\
\hline $\begin{array}{l}\text { 汎用 NR Latex } \\
\text { HA, LA Type }\end{array}$ & $60<$ & $\begin{array}{l}\text { RC } 60.0 \% \min \\
\text { NRC } \quad 2.0 \% \max \end{array}$ \\
\hline $\begin{array}{l}2 \text { 回遠心分離 } \\
\text { DC LATEX }\end{array}$ & $60<$ & $\begin{array}{l}\text { NRC } 0.5 \sim 0.8 \% \text { 耐老化性が不足. } \\
\text { 被膜が淡色, やや加硫が遅い. }\end{array}$ \\
\hline $\begin{array}{l}\text { 脱タンパク } \\
\text { Latex DP LATEX }\end{array}$ & $60<$ & タンパク質を取除いたラテックス. \\
\hline $\begin{array}{l}\text { 超低アンモニア } \\
\text { Latex }\end{array}$ & $60<$ & NH3 $0.1 \% \geqq$ 例 ULACOL \\
\hline 高濃縮 Latex & $66<$ & $\begin{array}{l}\text { クリーミング法, 蒸発法等 } \\
\text { 例 : TRH-70 }\end{array}$ \\
\hline 高濾過性 Latex & $60<$ & マイクロフロックが少ない \\
\hline
\end{tabular}

注：NRラテックスの国際規格については, ISO 2004:1997を参 照. DRC: dry rubber content. HA: High ammonia, LA: Low ammonia, RC: Rubber content, NRC: Non rubber content, TZ: TMTD と ZnO を原料とする保存剤，DC: Double centrifuge, DP: De-protein, ULACOL, TRH-70: レヂテックス 社商標.
や用途に応じた物性が求められる分野では, 特殊なNR ラ テックスが製造されている。

例えば，特殊な NRラテックスには，アレルゲンを極力 除いた脱タンパクラテックス，ほとんど臭いが気にならな い超低アンモニアラテックス，速乾性に優れた高濃縮 NR ラテックスなどがある．脱タンパクラテックスは，皮膚へ の刺激性を軽減する目的で使用されることが多く, 超低ア ンモニアラテックスは, NRラテックス特有のアンモニア 刺激臭を気にする人や作業環境の改善を目的として選択さ れることが多い. 高濃縮ラテックスは乾燥が速いことから, 古くから靴用の吊り込み糊や仮止め接着用として定評があ り現在も革靴やスニーカーなどの製造工程で使用されてい る.また，生地同士をミシン掛けするときの仮止めなどで も使用されている.

表1より 2013 年における NRの世界の生産量は約 1,195 万トンで，その約 $10 \%$ がNR ラテックスと考えられる.日 本では，手袋・カーペット・医療用品・接着剤用途で使用 され，輸入量は 7 千 1 万トンと推測される. 成型製品な どの海外移転が進む中，カーペットや粘接着剂用途での一 定規模の需要があるとされている.

\section{NRラテックスを使用した接着剤の主な用途}

NRラテックスを原料とする粘・接着剤として，90年代 半ばまではフォームラバー・カーペットバッキング, アル バム用粘着剤，製靴用接着剂，作業手袋用，ゴムホース用 接着剤等が主流であったが，住宅のフローリング化，デジ タルカメラの普及によるアルバム台紙の減少，製靴，作業 手袋，ボール等の生産の多くが海外に移転したことにより 従来の接着剂需要が減少した一方で，ゴム糊として有機溶 剂に溶解したゴム系粘・接着剤の水性化によりラテックス 系の接着剤の需要が増加している。VOC対応，作業環境

表3ＮRラテックスを使用した接着剤例

\begin{tabular}{|c|c|c|}
\hline 分 野 & 接着剽種類 & 用途例 \\
\hline 紙加工用 & $\begin{array}{l}\text { アドヘア糊 } \\
\text { コールドシール剤 } \\
\text { リシーラブル糊 }\end{array}$ & $\begin{array}{l}\text { 封筒用 } \\
\text { 梱包用 } \\
\text { 三つ折り封筒 }\end{array}$ \\
\hline アルバム糊 & $\begin{array}{l}\text { 表糊 } \\
\text { 裏糊 }\end{array}$ & $\begin{array}{l}\text { フリーアルバム } \\
\text { 台紙ラミネート }\end{array}$ \\
\hline 繊維加工 & $\begin{array}{l}\text { ラミネート用 } \\
\text { カーペットバッキング } \\
\text { パーム用バッキング }\end{array}$ & $\begin{array}{l}\text { 布補修用接着剂 } \\
\text { 䋐毯, カーマット } \\
\text { 玄関マット }\end{array}$ \\
\hline 粘着テープ & $\begin{array}{l}\text { マスキングテープ } \\
\text { 塩ビテープ }\end{array}$ & $\begin{array}{l}\text { 和紙テープ } \\
\text { 粘着剂 }\end{array}$ \\
\hline 製靴用 & $\begin{array}{l}\text { 吊りこみ糊 } \\
\text { テープ糊 } \\
\text { ゴムトッピング用糊 } \\
\text { 総ゴム用糊 }\end{array}$ & $\begin{array}{l}\text { 甲材吊り込み用 } \\
\text { 未加硫ゴムテープ } \\
\text { 加硫接着用 } \\
\text { 長靴メリヤス用 }\end{array}$ \\
\hline ゴム手袋 & $\begin{array}{l}\text { ゴム粉接着 } \\
\text { 軍手滑り止め加工用 }\end{array}$ & $\begin{array}{l}\text { 作業ゴム手袋 } \\
\text { 作業手袋 }\end{array}$ \\
\hline 粉塵防止剤 & 粉塵固定用 & 土埃り防止用 \\
\hline ボール用 & $\begin{array}{l}\text { カーカス用 } \\
\text { 皮革 } / \mathrm{EVA} \text { フォーム } \\
\text { 皮革 / 布ラミネート用 }\end{array}$ & $\begin{array}{l}\text { 各種革製ボール用 } \\
\text { サッカー, バレー, } \\
\text { バスケット用 }\end{array}$ \\
\hline
\end{tabular}


改善，健康志向の高まりなどが要因により，車載用ワイヤ ーハーネス用テープの水性化, スポーツ競技の公式球や学 童用布靴の接着剂の水性化が進んでいる。また紙用の機能 性接着剂にも NRラテックスを使用した接着剤が広く使わ れている．90年代初めに開発されたハガキ，封筒用の可 剥離接着剂はラテックス本来の自着性（Autotack）を利 用した機能性接着剂である。「剥がせる接着剤」「疑似接着 剂」など様々な呼称で呼ばれている，封緘用接着剤であり ながらきれいに剥がれる。従来の封緘用接着剤は，きれい に剥がす事が難しく，開封したことが解るようになってい たが，この接着剤は二度と同じようには接着しない事で， 封緘シールとしての役割を果たしている。日本では親展ハ ガキとして，海外では三つ折り封筒の縁糊として親展性の 高い郵便物に使用されている。ペーパーレスの時代ではあ るが，個人情報が記載された親展性，機密性が求められる 文書にはこのような機能性の接着剤が求められている.

NRラテックスを使用した接着剤の主な用途を述べた が，これらの接着剤が根強く支持されている理由として挙 げられるのは，NRラテックス独特の素材感である．アル バム台紙の粘着剂は本来の写真を貼る用途としては減少し ているが，現在でも写真や書類の収集，手紙やはがき等の 保存用として活用されている。 また，可剥離用粘着剂や粘 着テープの粘着層としても応用されている.NRラテック スを使用した接着剤は，NRの持つ柔らかい剥離感，つま り何百回，剥がしたり貼り付けたりしても変わらない感触 で，寒い日でも真夏でも，1分後にはがしても 1 年後には がしても，ゆっくりはがしても，速くはがしてもほぼ同じ 剥離感を有し，他の合成樹脂系粘着剂では代替できない.

次の項ではこのNRラテックスの素材感に使用目的にそ った機能性を付与する化学変性したNRラテックスについ て述べる。

\section{NRラテックスの変性体}

2 項で述べたとおり，接着剤用途の場合，NR ラテック スをそのまま混合して使用するより，一度化学的に変性し て中間原料を製造し，その後に接着剤として配合し製品化 するものが多いので，その原料の選択は重要である.

主な NRラテックスの変性体を表 4 に示す.

\section{1 前加硫NR ラテックス}

前加硫 NR ラテックスは, 水に分散した状態で前加硫 (架橋) したもので，加硫剤やパーオキサイドを加えた状 態で加熱工程を経て製造される。乾燥しただけで被膜は加 硫ゴム物性が得られるが，通常は $80 \sim 100{ }^{\circ} \mathrm{C}$ で 30 分ほど 熱処理をすることでより確実な加硫ゴムが得られる．硫黄 加硫では引張強度が $35 \mathrm{MPa}$ ，パーオキサイド加硫でも 25 $\mathrm{MPa}$ 程度は得られる。トルエンなどの有機溶剤で膨潤は するものの不溶化し，耐油性，機械的安定性も向上する.
表4 NRラテックス変性体の分類

\begin{tabular}{|c|c|c|c|}
\hline 種類 & 変性体 & 概 要 & 特 徵 \\
\hline \multirow{3}{*}{$\begin{array}{l}\text { 前 } \\
\text { 加 } \\
\text { 硫 } \\
\text { ज } \\
\text { 厂 } \\
\text { y } \\
\text { ク } \\
\text { ス }\end{array}$} & 硫黄系前加硫 PCL & -C-Sx-C- & $\begin{array}{l}\text { 硫黄架橋. 乾燥 } \\
\text { のみでも加硫ゴ } \\
\text { 厶製品が得られ } \\
\text { る. 浸漬製品. } \\
\end{array}$ \\
\hline & パーオキサイド架橋 & -C-C- 過酸化物 & $\begin{array}{l}\text { 有機過酸化物架 } \\
\text { 橋 SS-58ニトロ } \\
\text { ソァミンフリー }\end{array}$ \\
\hline & $\begin{array}{l}\text { アクリルグラフト } \\
\text { 共重合体 }\end{array}$ & $\begin{array}{l}\text { MG ラテックス } \\
\text { BAG ラテックス } \\
\text { EMG ラテックス }\end{array}$ & $\begin{array}{l}\text { MMA グラフト } \\
\text { 機械的安定性, } \\
\text { 耐候性 BA グラ } \\
\text { フト粘着性, 柔 } \\
\text { 軟性 GMA グ } \\
\text { フト架橋性 }\end{array}$ \\
\hline \multirow{2}{*}{$\begin{array}{l}\text { ラ } \\
\text { テグ } \\
\text { ッラ } \\
\text { クフ } \\
\text { スト } \\
\text { 系 }\end{array}$} & その他 & $\begin{array}{l}\text { STG ラテ } \\
\text { SG ラテッ }\end{array}$ & $\begin{array}{l}\text { スチレングラフ } \\
\text { ト前加硫 MMA } \\
\text { グラフト }\end{array}$ \\
\hline & $\begin{array}{l}\text { 解重合 MMA グラフ } \\
\text { トラテックス }\end{array}$ & $\begin{array}{l}\text { DPL ラテックス } \\
\text { DPMG ラテックス }\end{array}$ & $\begin{array}{l}\text { 低分子量化, 粘 } \\
\text { 着性, 耐候 性, } \\
\text { 粘着性 }\end{array}$ \\
\hline 他亭 & $\begin{array}{l}\text { エポキシ化ラテック } \\
\text { ス }\end{array}$ & ENR & $\begin{array}{l}\text { 耐油性, 架橋性 } \\
\text { 高い. }\end{array}$ \\
\hline
\end{tabular}

(注) MG:MMA グラフト共重合ラテックス, BAG: ブチルアクレレー 卜, EMG:グリシジルメタアクリレート, STG:スチレングラフト, DPMG: 解重合 MMA グラフト, ENR: エポキシ化天然ゴム

薄く強いラテックス浸漬製品などで使用されるほか, 不織 布用バインダー，缶シールなどのシール，ガスケット用途 で使用される。加硫度は加硫剤の配合量や種類に応じて段 階的に設定しているものもある. 過酸化物加硫ラテックス はニトロソアミンが検出されないことからニトロソアミン フリーの架橋タイプとして玩具や生活用品に使用できる. 還元剤として通常アミン類を用いるが，それ以外ではフル クトースを使用することもある。

\section{2 アクリルグラフト共重合ラテックス}

図 3 にアクリルグラフト共重合体の模式図を示す。

図3では天然ゴム主鎖のポリイソプレンにPMMAが枝状に 結合している．実際には水中に分散しているゴム粒子の表面 にMMAが浸透をした形で結合していると考えられる.

MMA をグラフト共重合したラテックスは古くから製造 されており，もっとも多く製造される化学変性体の一つで ある。他のモノマーとしては，スチレン，ブチルアクリレ ート，グリシジルメタアクリレート，およびこれらの複合 体がある。

グラフト共重合ラテックスはNRラテックス変性体の中 でも最も多くの接着剤用途に使用されている. その理由と して，NRラテックスと比較して飛躍的に機械的安定性が 向上し，長時間の塗工ラインにおいても安定した塗工適性 を得られることがあげられる，NRラテックスでも低スピ ード塗工や厚塗り塗工の長時間の塗工には耐えられるが,

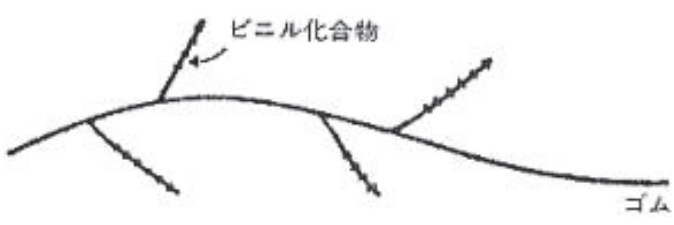

図3アクリルグラフト共重合体の模式図 


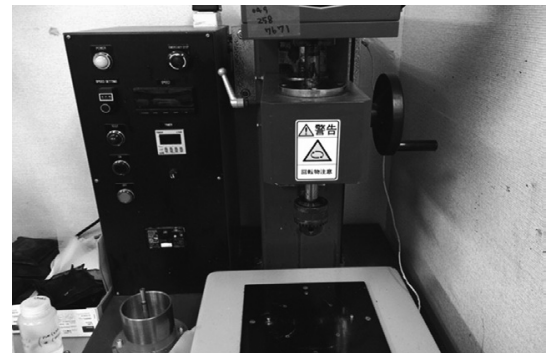

図4 マーロン試験

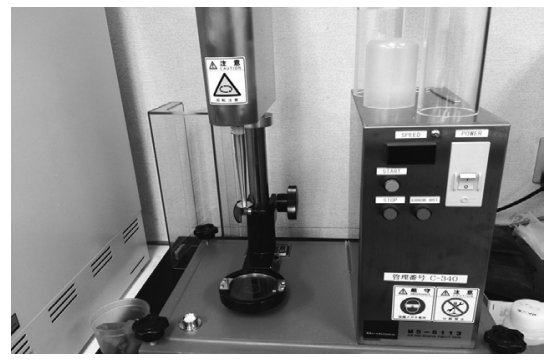

図 5 クラクソン試験機

薄く高速に塗工する場合, 乾燥が早く, 凝集物が発生しや すくなり塗工トラブルを起こしやすくなる.

例えば，通常の合成ゴムラテックスの機械的安定性はマ ーロン試験機（図4）で測定評価するが，NRラテックス では通常クラクソン（Klaxon）式安定度試験機（図5）に より機械的安定性を測定する。クラクソン式試験法は，一 定寸法の回転円板を試料ラテックス中で高速回転させ，ラ テックス中で凝固粒が発生し始めるまでの時間を測定する ものである. ISO 2004:1997ではラテックス中で凝固粒が 発生し始めるまでの時間は，650 sec 以上となっている. 一方マーロン試験機は, $1000 \pm 20 \mathrm{rpm} / \mathrm{min}$ の回転数を保 つことのできる装置と，垂直なシャフトをもつステンレス 鋼製回転円板，ステンレス鋼製試料容器及び最大目盛が $30 \mathrm{~kg}$ 又は $50 \mathrm{~kg}$ で，最少目盛が $200 \mathrm{~g}$ の台ばかりからなる 試験装置を使用する。この装置は回転円板を試料容器に一 定の圧力で押し付けたまま一定速度で回転させ，その際生 成するラテックス中の凝固分を測定するもので, 試料容器 の底にはポリエチレン製ライナーを取り付け，また回転円 板の下面と試料容器の底板の上面には，ラテックスが循環 するように溝を設けてある。（注：ポリエチレン製ライナ 一の材質は, 密度 $0.921\left(23{ }^{\circ} \mathrm{C}\right)$, メルトフローレート （MFR）0.25のものを標準とする.）

NR ラテックスはマーロン試験機では測定できないほど 機械的安定性に問題がある。しかし適性にグラフト共重合 ラテックスに変性した場合は，マーロン試験機で測定可能 なレベルにまで向上し，工業的に連続して塗工が可能にな り，応用範囲が広がり，NRラテックスの特長を維持しな がら優れた特長を発揮することができるようになる。 三つ 折り封筒などの塗工機ではその違いは明らかで，NRラテ ックスベースの接着剤では 1 ～時間おきに塗工機を洗浄
するなどのメンテナンスが必要なのに対して，グラフトラ テックスでは 24 時間の連続塗工が可能である。これはグ ラフト化することにより乳化分散性が向上したことに起因 すると考えられる。

グラフト共重合の中でも MMAグラフト共重合体の場 合，アクリルの含有率により，硬さや極性をコントロール することができ，接着力や粘着力，凝集力などのコントロ ールができるようになる，グラフト共重合であるため，シ ス-1,4-ポリイソプレン構造の柔軟性と自着性をある程度維 持している点も接着剤としての優位性になっている.

また，ブチルアクリレートやスチレン，グリシジルメタ アクリレートなどをグラフト重合したものもあり，それぞ れに独特の性状を発現するようになる．EMGラテックス のようにグリシジルアクリレートをグラフトしたものは, 柔軟性のある皮膜が架橋剂を加えることで硬いプラスチッ ク状に硬化するものもある。また，NRラテックスを一度 解重合してグラフト共重合したものは，造膜性の良く，粘 着性のある柔らかい粘着剂原料として使用でき, 粘着付与 郕の配合により，粘着特性が幅広く設計できる。

\section{3 解重合 NRラテックス (DPL：Depolymerized NR Latex)}

解重合ラテックスはNRラテックスを化学的に酸化し, 低分子化したラテックスであり，粘着性が強いことが特徴 である。脱タンパクラテックス（De protein latex）と同 じDPLと表記される場合があるので注意されたい。

NR系の高分子粘着性付与郕として代表的なものにはマ レーシアゴム研究所 (Rubber Research Institute of Malaysia; RRIM) の研究グループにより開発された $\mathrm{HRH}$ ラテックスとこのDPLがある，HRHラテックスはヒドロ キシルアミン，ヒドラジン，またはパラフェニレンジアミ ンなどをNRラテックスに添加することにより，可塑度の 低下や自然増加防止を図ったものであり，DPLは主とし て沖倉らによって開発された解重合NRラテックスが知ら れているが，ここではDPラテックスについて述べる.

有機溶剂系の「ゴムのり」の場合，空気中で素練りをする ことにより溶剤に可溶化しかつ粘着力が向上するようにコン トロールするが，ラテックスの場合素練りが出来ないため, 過酸化物により化学的に酸化することにより分子鎖を切断 し，低分子化を行う．数百万の分子量のNRラテックスが数 万程度の分子量になる。 ラテックス特有の，ポリマーゲルを 残した解重合ラテックスとポリマーゲルを無くした解重合ラ テックスを造り分け製造することも可能である.

一般的な解重合 NR ラテックスと粘着付与樹脂の配合例を 表 5 に示す. 水性粘着剤では出しにくいボールタックと粘着 力が向上させることができる，用途としては，各種テープ用 粘着剤, 有機溶剤ゴム系粘着剤の水系化, 再剥離型粘着郕な どに使用される．また，粘着性コントロールや剥離感の調整 
表 5 一般的な解重合 NR ラテックスと粘着付与樹脂の配合例

\begin{tabular}{|c|c|c|c|c|c|}
\hline \multicolumn{6}{|c|}{ NR ラテックス／解重合ラテックス／粘着付与剂配合例 } \\
\hline & 試料 & 1 & 2 & 3 & 4 \\
\hline \multirow{5}{*}{ 配合 } & NR Latex & 90 & 80 & 70 & 100 \\
\hline & DPL-51 & 10 & 20 & 30 & - \\
\hline & ロジンエステル ${ }^{*}$ & 80 & 80 & 80 & 80 \\
\hline & 老化防止剤 & 1 & 1 & 1 & 1 \\
\hline & 増粘剤 & 0.1 & 0.1 & 0.1 & 0.1 \\
\hline \multirow{4}{*}{$\begin{array}{l}\text { 粘着 } \\
\text { 物性 }\end{array}$} & 粘着力 $(\mathrm{g} / 25 \mathrm{~mm})$ & 480 & 630 & 780 & 390 \\
\hline & ボールタック No. & 12 & 16 & 21 & 10 \\
\hline & 保持力（ずれ） & 0 & 0.4 & 1.7 & 0 \\
\hline & 耐水性 & $5 \mathrm{~min}$ & $30 \mathrm{~min}$ & $24 \mathrm{hr}<$ & $5 \mathrm{~min}$ \\
\hline
\end{tabular}

表6 解重合ラテックスにMMAグラフトした, DPMG ラテックスの 配合例

\begin{tabular}{|c|c|c|c|c|c|c|}
\hline \multicolumn{7}{|c|}{ DPMG の粘着剂配合物性 } \\
\hline \multirow{2}{*}{\multicolumn{2}{|c|}{$\begin{array}{c}\text { ベース樹脂 } \\
\text { 配合 樹脂 / } \\
\text { DPMG-40 }\end{array}$}} & \multirow{2}{*}{\multicolumn{2}{|c|}{ 対象 }} & \multicolumn{3}{|c|}{ 樹脂（YS ポリスターU-115） } \\
\hline & & & & $60 / 100$ & $80 / 100$ & $100 / 100$ \\
\hline \multicolumn{2}{|c|}{ 相溶性 } & \multicolumn{2}{|c|}{ 透明 } & 透明 & 透明 & 透明 \\
\hline \multicolumn{2}{|c|}{ ボールタック No. } & \multicolumn{2}{|c|}{3 以下 } & 3 以下 & 3 以下 & 3 以下 \\
\hline \multirow{6}{*}{$\begin{array}{l}\text { 粘着力 } \\
(\mathrm{g} / 25 \mathrm{~mm})\end{array}$} & \multirow{4}{*}{ 対 SUS } & $0^{\circ} \mathrm{C}$ & 10 & 1670 & $1250 \mathrm{~S}^{*}$ & $875 \mathrm{~S}^{*}$ \\
\hline & & $23^{\circ} \mathrm{C}$ & 10 & 1080 & 1390 & $1500 \mathrm{~S}$ \\
\hline & & $60^{\circ} \mathrm{C}$ & 120 & 1140 & 1430 & 1655 \\
\hline & & 耐水性 & 0 & 960 & 1170 & 1000 \\
\hline & 対 PP & $23^{\circ} \mathrm{C}$ & 20 & 920 & 1340 & $240 \mathrm{~S}$ \\
\hline & 対 PE & $23^{\circ} \mathrm{C}$ & 5 & 450 & 470 & $60 \mathrm{~s}$ \\
\hline \multirow{2}{*}{$\begin{array}{c}\text { 保持力 } \\
\text { (hr) }\end{array}$} & 対 SUS & $60^{\circ} \mathrm{C}$ & $\begin{array}{c}0 \\
(\mathrm{~mm} / 3 \mathrm{hr})\end{array}$ & $\begin{array}{c}0 \\
(\mathrm{~mm} / 3 \mathrm{hr})\end{array}$ & $\begin{array}{c}0 \\
(\mathrm{~mm} / 3 \mathrm{hr})\end{array}$ & 0.1 \\
\hline & 対 PE & $40^{\circ} \mathrm{C}$ & 0.8 & $\begin{array}{c}1 \\
(\mathrm{~mm} / 3 \mathrm{hr})\end{array}$ & $\begin{array}{c}2 \\
(\mathrm{~mm} / 3 \mathrm{hr})\end{array}$ & 1.4 \\
\hline \multicolumn{2}{|c|}{$\begin{array}{c}\text { SAFT }\left({ }^{\circ} \mathrm{C}\right) \\
\text { 対 SUS }\end{array}$} & \multicolumn{2}{|c|}{100} & 111 & $96 *$ & 53 \\
\hline
\end{tabular}

ヤスハラケミカル（株）社製テルペンフェノール，DPMG-40：(株）レ ヂテックス社製

$\mathrm{S}$ ：ステックスリップ *: 凝集破壊

テープ：PETフィルム, 糊厚 $30 \mu \mathrm{m}$, 乾燥 $105^{\circ} \mathrm{C} \times 5 \mathrm{~min}$, ボールタック J.DOW 法 $\left(23^{\circ} \mathrm{C}\right)$

粘着力 $180^{\circ} \mathrm{C}$ 剥離度, 耐水性 : $23^{\circ} \mathrm{C}$ 水中に 1 日浸漬させ, 1 日乾燥させた

後, 対 $\mathrm{SUS} 180^{\circ} \mathrm{C}$ 剥離強度測定, SAFT ： $1 \mathrm{~kg}$ 荷重 $25 \times 25 \mathrm{~mm}$ （対 SUS, $40^{\circ} \mathrm{C}$ から $2^{\circ} \mathrm{C} / \mathrm{min}$ 昇温の落下温度)

\section{のためアクリルエマルジョンを配合することもある.}

さらに解重合ラテックスに MMAグラフトした, DPMG ラテックスの配合例を表 6 に示す。ボールタックは低いも のの，接着力は強く，特に極性のある素材への粘着力が高 くなる傾向がある。また，ポリプロピレンやポリエチレン のような非極性ポリマーへも良好な粘着力を示し, 解重合 NRラテックスに比較して, 分子量の経時変化が比較的安 定している.

\section{4 エポキシ化NRラテックス}

エポキシ化NRラテックスは，耐油性に優れた性質を示 し，エポキシ化度50\%で白灯油に対してほほNBRに近い 耐油性が得られる.シリカ等の分散安定性やウェットグリ ップ性を示すことから，夕イヤの材料として早くから注目 を集めているが，接着剤としての用途は今後の開発が待た れる.NRラテックスの構造上，二重結合が比較的容易に エポキシ化することから，エポキシ化ラテックスの開発は 早くから開始されたが，ジエン系の固形ゴムの表面処理法 として使えるのではないかと着想して研究をはじめ，パウ ダーフリー，ノンハロゲンの表面処理方法として実用化し
た。精密ゴム部品分野や粉末，ハロゲン処理を嫌う分野で 最適な表面処理法と考えている.

\section{6. お わ り に}

将来を見据えラテックス分野では以下に示すような研究 開発テーマが有望であると考えられる.

（1）アレルギー対策製品

NR ラテックスはタイプIの蛋白質アレルギーや加硫 (促進) 剂による夕イプIVのアレルギーの可能性があるの で，合成系のラテックスとして，IR（ポリイソプレン） ラテックスを使用して低温での架橋化を行い，手袋などの 医療用を目指したアレルギーの全くない高強度製品開発が 望まれる。また，ある種の金属化合物をIRラテックスに 使用すると柔らかさを保ちながら高強度化が達成された。 これまでは架橋は， C - S 結合か $\mathrm{C}-\mathrm{C}$ 結合であったが， 新たな結合（配位結合）により高強度化が達成できた。但 し，アレルギーに関しては，金属化合物であるため金属に よるアレルギーの発症の懸念が想定される.

(2) グラフト重合の制御

以上述べてきたように，NRラテックスにラジカル重合 法でMMAなどでグラフト重合を行っているが，ラジカル 重合法のため制御が重要となる．NRラテックスのグラフ 卜重合機構の検討から，グラフト重合がより制御され，グ ラフト効率をある範囲内で制御できるように研究開発を進 めている。これによりマレーシア, タイ, ベトナム以外の NRラテックスでも，産地に依存せずより安定したグラフ トラテックスが効率的に製造可能になると考えている.

最後に，NRラテックスのタンパク質の役割をさらに探 求し, Heavea 樹以外の植物からのゴムの利用に応用する ことで新たなゴムの時代になると考えている.

\section{References}

1) Okikura, M.: "Emulsion Latex Handbook". Taiseisha, Tokyo, P.575 (1982)

2 ) Kunisawa. S.: “Emulsion Latex Handbook”.Taiseisha Tokyo, P.5. (1982)

3 ) Okikura. M.: "Latex Emulsion no Saishin Oyo Gijutsu", Chunichisha, Tokyo, P.9 (1991)

4 ) Green Tec Award 2014.: "Industrial Emergence of Natural Rubber from Dandelion"

5 ) http://www.globalnote.jp/post-1085.html

\section{日本語表記参考文献}

1 ）沖倉元治：エマルジョン・ラテックスハンドブック，大成社, 東京, p. 575 (1982)

2 ）国沢新太郎：エマルジョン・ラテックスハンドブック，大成社, 東京, p. 5 (1982)

3 ) 沖倉元治：ラテックス・エマルジョンの最新応用技術, 中日社, 東京, p. 9 (1991)

4) Green Tec Award 2014 「RUBIN-タンポポから作られた天然ゴ 厶の工業利用」日刊工業新聞 2014 年 7 月 